\title{
Socratic Appetites as Plotinian Reflectors: A New Interpretation of Plotinus's Socratic Intellectualism
}

\author{
Brian Lightbody
}

Enneads I: 8.14 poses significant problems for scholars working in the Plotinian secondary literature. In that passage, Plotinus gives the impression that the body and not the soul is causally responsible for vice. The difficulty is that in many other sections of the same text, Plotinus makes it abundantly clear that the body, as matter, is a mere privation of being and therefore represents the lowest rung on the proverbial metaphysical ladder. A crucial aspect to Plotinus's emanationism, however, is that lower levels of a metaphysical hierarchy cannot causally influence higher ones and, thus, there is an inconsistency in the Egyptian's magnum opus, or so it would seem. Scholars have sought to work through this paradox by positing that Plotinus is a "paleolithic Platonist" or Socratic. The advantage of this approach is that one may be able to resolve the tension by invoking Socrates's eliminativist solution to the problem of weakness of will, as found in The Protagoras. In the following article, I argue that such attempts are not wrong-headed just underdetermined. They take up the standard reading of Socratic moral intellectualism, namely the "informational" interpretation and, therefore, fail to render a coherent view of Plotinus's moral philosophy. The following paper, in contrast, utilizes a new reading of intellectualism advanced by Brickhouse and Smith, which, when subtended with a "powers approach" to causality, resolves the aforementioned, problematic passage of Enneads.

Sections 352A-352E of Plato's Protagoras, represent the locus classicus of Socrates's denial of akrasia or weakness of will. According to Socrates-and in contrast to what he and Protagoras regard as the "common view" of agential action-reason cannot be overcome by desire, and, therefore, weakness of will is impossible: one cannot act against one's best judgment, all things considered. ${ }^{1}$ So-called, 'weakness of will,' Socrates

\footnotetext{
${ }^{1}$ See Plato's Protagoras (352a-d) in Plato the Complete Works, ed. John M. Cooper, trans. Stanley Lombardo and Karen Bell (Indianapolis: Hackett Publishing, 1997), 746-791.
} 
explains, is caused by ignorance and, in particular, mismeasurement. ${ }^{2}$ Proximity to painful or pleasurable circumstances causes agents to either over or underestimate the real value of such things and, therefore, leads them to make bad choices, even though said 'choices' are involuntary. The upshot of Socrates' approach is that the mere re-evaluation of a destructive desire is enough to neutralize its efficacy or so that standard reading of Socratic intellectualism would have it.

The above summation of Socrates's analysis of akrasia seems reasonably straightforward. However, as demonstrated by the recent work, Socratic Moral Psychology by Thomas Brickhouse and Nicholas Smith, the standard account is grossly underdetermined. Critical features of Socrates's explanation remain unclear. In a series of incisive questions the authors capture the problems with the traditional Socratic understanding of akrasia. Paraphrasing the most important of these queries the authors ask: 'How does the mere proximity to pleasurable or painful things cause subjects to mispresent the real qualities of these objects?' 'How does knowledge, here understood as correct measurement, overcome the initial value some option appears to have?' Moreover and most importantly the authors inquire: 'How do we square the standard interpretation of sections 352a-E with other passages from Plato's early work where Socrates seems to affirm that appetites, fear, (along with other emotions) do have causal roles to play when it comes to determining our choices?'

The above questions, causal in structure, become all the more perplexing when applied to the work of Plotinus. For in the recent Plotinian secondary literature, there have been renewed efforts to interpret Plotinus, in the words of Lloyd Gerson, as a "paleolithic Platonist" that is, a Socratean. ${ }^{3}$ More clearly stated, the debate in the secondary literature regarding Plotinus's Socratic heritage pivots on the kind of intellectualist position Plotinus adopts. Gerson, for example, in his paper, "Plotinus on Weakness of Will: The Neoplatonic Synthesis" argues for a "blended view." Plotinus' thesis of akrasia is, really, a diluted Socratic position because it is one that combines insights not just from Socrates, but the

\footnotetext{
${ }^{2}$ See Protagoras (357A-E).

${ }^{3}$ Lloyd Gerson, "Plotinus on Weakness of Will: The Neoplatonic Synthesis" in Weakness of Will From Plato to the Present, Ed. Tobias Hoffman Washington; D.C.: Catholic University of America Press, 2008, 42-57, 42.
} 
middle and later Plato, Aristotle, and the Stoics. ${ }^{4}$ Others, most notably Robert Van Den Berg, hold that Plotinus is a Socratic intellectualist-full stop. ${ }^{5}$ The difference between the two interpretations lies with the passages utilized to support Plotinus's Socratic attitude. Although both scholars offer similar yet distinct positions regarding the influence of Socrates on Plotinus, the main question posed remains the same: "Why is ignorance the cause of vice?" Their answer, in broad brushstrokes, is that the Self identifies with its composite (soul and body) and turns away from its actual realization, which is that of an immaterial being, Soul (Enneads, I.1.9 15-18). ${ }^{6}$

Notice, however, that this answer remains firmly focused on the Plotinian side of the "Plotinus is a Socratic moral intellectualist" identity statement and not on the Socratic. My paper intends to correct this deficiency by fleshing out the Socratic segment of the above equation. My starting point will be a different question: "What causes ignorance?" By taking my cue from the recent work of Brickhouse and Smith I argue that desires, for Plotinus, are not purely informational as they are under the standard Socratic intellectualist model but are neither causal in the Platonic or Aristotelian senses. ${ }^{7}$ Appetites and passions, at least from the lower self's standpoint, play a "causing relationship" as John Heil would put it, in terms of how objects are presented to the mind for further evaluation.

\footnotetext{
${ }^{4}$ Lloyd Gerson, "Plotinus on Weakness of Will: The Neoplatonic Synthesis" in Weakness of Will From Plato to the Present, Ed. Tobias Hoffman Washington; D.C.: Catholic University of America Press, 2008, 42-57.

5 Robert Van Den Berg "Plotinus's Socratic Intellectualism" Proceedings of the Boston Area Colloquium in Ancient Philosophy, Vol. XXVIII eds. Gary M. Gurtler, SJ, and William Wians, Brill: Leiden/Boston 2013, pp.217-231. Gary Gabor, “Commentary on Van Den Berg” (Plotinus's Socratic Intellectualism) Proceedings of the Boston Area Colloquium in Ancient Philosophy, Vol. XXVIII 2012, eds. Gary M. Gurtler, SJ, and William Wians, Brill: Leiden/Boston 2013, pp. 232240.

${ }^{6}$ All references to Enneads will be from the Armstrong translation unless otherwise noted. See Plotinus. Enneads, Volume I-VIII: Translated by A. H. Armstrong, Loeb Classical Library 440. Cambridge, MA: Harvard University Press, 1969.

${ }^{7}$ Where for the former, " $<\ldots>$ at least sometimes or in some cases, our appetites could lead us to act in ways that were contrary to what we believed-even as we acted-were best for us". (See Thomas BrickHouse and Nicholas Smith, Socratic Moral Psychology, (Cambridge University Press, 2010,199, and Book IV Republic) "<...> and where for the latter passions could de-activate reason, momentarily, causing one to make a mistake regarding one's practical reasoning" (see Aristotle, NE 1110b, 25, 1113b, 35).
} 
By underpinning Plotinus's view of akrasia on this new understanding of Socratic moral psychology where desires may appear to the self to be more enticing than they really are, I can explain, in the words of Gary Gabor, "the lower soul's failure to submit to instruction by the higher soul" while recommitting Plotinus to a robustly, undiluted, Socratic position. ${ }^{8}$

To facilitate the path to my conclusion, I divide my paper into three sections. First, I look at the core components of the standard view of Socratic Intellectualism by examining the critical sections from Protagoras 352 as well as the gloss on these passages from two leading figures of early Platonic studies, Terry Penner and Naomi Reshotko. My hope in examining these passages is to bring the informational account of Socratean desires into sharper relief and to pave the way towards a reanalysis of Socrates' akratic position. In section two, I explain Brickhouse and Smith's new model of Socratic moral psychology. Although I think their position is both philologically and philosophically sounder than the standard view, there remains one troubling problem regarding the etiological relationship between appetites and orthos logos or right reasoning. I fix this problem by invoking a solution borrowed from John Heil that he calls a "powers interpretation" of causality. In the final section, I apply my reading to key passages in the Enneads that seem to deal with akrasia-at least as interpreted by scholars in the secondary literature-to reveal what I hope to be a new interpretation of Plotinian weakness of will that reaffirms a robust Socratic reading.

\section{The Standard View of Socratic Moral Intellectualism: The Informational Account}

It is in section 352 of the Protagoras where we first see a brilliant but profoundly counter-intuitive denial of akrasia or weakness of will. The first step in what might be called Socrates's eliminativist position on weakness of will, appears when he makes the following comment regarding knowledge. Socrates says:

What do you think about knowledge? Do you go along with the majority or not? Most people think this way about it, that it is not a powerful thing, neither a leader nor a ruler. They do not think of it in that way at all; but rather in this way: while knowledge is often present in a man, what rules him

\footnotetext{
${ }^{8}$ Gary Gabor, “Commentary on Van Den Berg” (Plotinus's Socratic Intellectualism”), 234.
} 
is not knowledge but rather anything else---sometimes anger, sometimes pleasure, sometimes pain, at other times love, often fear...(Protagoras, 352b-c Trans. Bell and Lombardo)

It is in thinking about knowledge itself that Socrates begins his opening salvo regarding the idea of the hoi polloi which posits that weakness of will is a fundamental feature of the human condition. Socrates wishes to demonstrate that thinking about knowledge as powerless when compared to appetite or pathos is clearly mistaken. The first part of Socrates' argument demonstrates that the theory of action accepted by most individuals, namely hedonism, requires calculation. Hedonism, of course, holds that individuals should seek pleasure and avoid pain. However, pleasure and pain, so Socrates contends, are infused with cognition: the individual must understand how to weigh actions such that more pleasure and less pain will befall the individual in the long-run.

It is because both wants and dislikes are cognitively infused that scholars like Penner and Reshotko call Socratic desires, despite straining against our intuitions, "informational". A desire is never raw, never a mere "hot" or "go" source of propulsion as Alfred Mele would call it. ${ }^{9}$ Desires, according to the standard view, rather, are first and foremost evidentiary; they serve as reasons within a broader belief system. According to the standard approach, it is not as though we are not under the influence of non-rational desires or fears but that in order for either of these things to be engines of action, one must provide a judgment about them. As Penner explains Socrates' account of action using one of his favorite go-to examples, the eating of pastry:

If in the particular circumstances I come to believe that eating this pastry is the best means in the circumstances then in plugging this belief into the desire for whatever is best in these circumstances, my rational desire for what is best becomes the desire to eat this pastry. Rational desires adjust to the agent's beliefs. The only way to influence my conduct is to change my opinion". ${ }^{10}$ (Penner's italics)

What Socrates has initiated, so this reading affirms, is a transmutation of sorts: rational desire (boulesis) becomes what we contemporary thinkers might call "interest". To quote Penner once more there is "a plugging in or an infusion of belief into desire when one

\footnotetext{
${ }^{9}$ For more on the empirical psychology of "hot" and "cool" responses see Alfred Mele's discussion in Backsliding: Understanding Weakness of Will (Oxford University Press, 2014: 81-84).

${ }^{10}$ Terry Penner, "Socrates and the Early Dialogues" The Cambridge Companion to Plato, Richard Kraut Ed. (Cambridge University Press 1992: 121-169, 128).
} 
chooses". In following my self-interests, I pursue not just what is appealing to me or drives me full stop, but what I also take to be, via rational judgment, the why or justification behind this appeal-I rationalize my desire and bring it in line with my belief system. Thus, according to Socrates, one cannot act against one's best interests because to act against one's best interest would entail knowingly choosing to do X instead of $\mathrm{Y}$ at time $\mathrm{T}$ even though one knows $X$ to be the best course of action, all things considered. The three conditions required for akrasia therefore: 1) $\mathrm{X}$ is viewed as the best course of action all things considered; 2) one is free to choose $\mathrm{X}$ but 3) one instead chooses $\mathrm{Y}$ cannot be fulfilled. ${ }^{11}$ Socrates reasons that $\mathrm{Y}$ must have appeared to be better than $\mathrm{X}$ prior to the subject making the choice. Thus, the very concept of akrasia explodes.

The above rendering of agential motivation deflates akrasia on illocutionary grounds-the conditions for weakness of will cannot be fulfilled if one accepts the assumption that one always acts in accordance to what one believes to be best for one. The position, is, in fact tautological. But so too it then logically follows that if one does end up acting against one's best interest then such an act must be involuntary. Sub-optimal choosing is the result of ignorance.

The next part of Socrates argument purports to show the causal disconnect between one's suboptimal action and one's knowledge. In other words, Socrates seeks to explain how one may come to act in a sub-optimal fashion, even when one is free to do so and where one, of course, always pursues what appears to be in one's interest. It would seem to me that the second part of Socrates argument, then, must explain or explain away feelings of regret one often feels when one engages in what is later 'known' to be the wrong choice in order to explain fully or to reduce akrasia to mere ignorance.

Socrates introduces his measurement analogy to help explain what we might call the emotive force of a moral failing-the knowledge that one was uncoerced in choosing the action one now regrets but chose the action out of ignorance and therefore was acting involuntarily. The analogy explains a fundamental phenomenological component of

${ }^{11}$ For the classic definitional account of weakness of will, see Donald Davidson's "How is Weakness of Will Possible", in Essays on Actions and Events, Philosophical Essays, Vol. 1 21-42, (Oxford University Press 2001: 22). 
akrasia, namely, that some choice appears to be the right action to make in a given circumstance ex-ante, but it is obviously the incorrect choice when viewed post facto.

Socrates's solution to this puzzle is telling:

Answer me this: do things of the same size appear to you larger when seen near at hand and smaller when seen from a distance, or not? They would agree. If our well-being depended upon this, doing and choosing large things, avoiding and not doing small ones, what would we see as our salvation in life? Would it be the art of measurement or the power of appearance? While the power of appearance often makes us wander all over the place in our actions and choices with respect to things large and small, the art of measurement in contrast, would make the appearances lose their power by showing us the truth, would give us peace of mind firmly rooted in the truth and would save our life. (Protagoras, 356c-e Bell and Lombardo trans.)

In looking at how an object may appear to be larger or really more desirable due to its temporal and perhaps spatial proximity to an agent I shall turn to another baked good example used by Penner in his paper entitled, "Knowledge vs Belief in the Socratic Psychology Theory of Action". Penner writes:

I see the oatmeal and raison cookie on the counter as I am about to pass through the kitchen. I form the belief that it would be best for me over all not to have the cookie. This belief is in full force as I begin to pass through the kitchen, but just as I come close enough to see more clearly the delectable and mouthwatering features of the cookie (and as chance-or nature-has it, I am at that instant also within closer reach of the cookie), I suddenly change my mind, reach out for it, and start eating it - saying to myself immediately it is in my mouth, 'what a fool I am'. In this sort of case I do, at the moment of action, believe that it will be best to reach out, grab, and eat the cookie. My vice at that moment is ignorance. ${ }^{12}$

Penner's argument is that the warm cookie directly before me appears to have properties that it would not otherwise have if it was more temporally and spatially remote. Properties that I now assess to be more important in having than, say, the positive feelings I possess when I stick to my diet, are now assessed, by me, as being less important than they were just a few moments earlier. What causes me to reassess my previous judgment according to Penner? It is not a raw desire, caused by the tempting properties of the cookie, as the common view of agential action would have it. The impetus, rather, is confined to the epistemic-it is my cognition and not my conative aspects that are affected by the cookie. As Penner explains (it is the (in)ability) "to hold on to one's intellectual grasp on

12 Terry Penner, "Knowledge vs. True Belief in the Socratic Psychology of Action", Apeiron, 3 1996: 199-230, 200-201. 
the situation as different gestalts on the same situation successively present themselves to the agent throughout the temporal context of the action". ${ }^{13}$ The irresistibility of the cookie, then, according to my new measurement of the mere gestalt or perception causes me to rationalize why it is in my best interest now to eat it. Neither the cookie nor the desire to have it are causally efficacious in themselves.

The same interpretation of perceptual remeasurement applies to pain. The recognition of some painful event appears to be insignificant the further away it is, temporally speaking. To use Socrates' own example of cautery, the cauterization of a wound appears to be more painful than allowing the wound to go untreated. The problem with viewing this surely painful practice of ancient cautery is that we are not fully aware that by not treating the wound it will become infected causing far more pain and likely death-something that is not in my best interest. I therefore reason to leave the wound uncauterized not out of fear, simpliciter but because of a new evaluation: it is not in my interest to have the wound cauterized at this time (Protagoras $354 \mathrm{~A}-\mathrm{E}$ ).

The upshot of the standard reading is that one may readjust one's actions by remeasuring one's evaluation of an object or situation-bracketing its propinquity and instead focusing on its intensity and duration in and of itself all of which may be measured. Such evaluation of course, presupposes that one truly possesses the knowledge of measurement where objects will be presented to the mind for evaluation in their true qualitative and quantitative terms, respectively.

\section{Challenging the Standard View}

The above characterization of Socrates's standard position is called the "informational view" by Brickhouse and Smith. In their now classic Socratic Moral Psychology, they pose several probing questions regarding the coherency and philological soundness of the standard position. I begin with the interpretative problems first. As they show, there are many places within the early Platonic corpus where the standard definition stands in tension with other passages within the same period. For example, in Laches 191 e4-7 Socrates claims that "some display courage in situations involving pleasure, and others

\footnotetext{
${ }^{13}$ Penner, "Knowledge vs. True Belief in the Socratic Psychology of Action”, 200.
} 
in situations involving pain, some in situations involving desire and others in situations involving fear" (trans. Robert Waterfield). ${ }^{14}$ But if such drives and feelings were purely informational then why would Socrates present them as causal forces that prevent from one doing what is right? For Socrates goes on to note that these same forces may cause others to “display cowardice" (Laches, 191 e 8). And again, if they were just informational then why would it be commendatory to resist their pull $?^{15}$ The standard interpretation, then, is simply inconsistent with the natural, interpretative implication of this passage. What's more, Brickhouse and Smith demonstrate that there are many, many more passages (like that of 191e of Laches) in the early Platonic corpus which are recalcitrant to an informational interpretation. ${ }^{16}$ It is clear, then, that some other interpretative solution must be tried.

What is most striking perhaps is that there is ample evidence in The Apology (considered by most scholars to be the very touchstone of Socratic thinking), to suggest that particular emotions like fear are not just informational but causal. ${ }^{17}$ The account is given in great detail by Brickhouse and Smith and I can't repeat it here in its entirety. Instead, I offer their conclusion drawn from a consideration of 21b1-23e3 of the work. They summarize their findings as follows:

1) Socrates interrogates someone, revealing that person's ignorance.

2) The person's pride is injured, they feel publicly humiliated, and become angry;

3) The person's anger leads the person to want to slander Socrates;

4) But the humiliation and their own pride are such that they cannot bring themselves to reveal the truth: that it was their own ignorance that led to their humiliation;

5) So instead they concoct the convenient story "what is commonly said against all philosophers"and accuse him of being a word-twisting, atheistic sophist;

${ }^{14}$ Plato, Meno and Other Dialogues (Charmides, Laches, Lysis), Trans. Robert Waterfield (Oxford University Press, 2005: 53).

${ }^{15}$ Brickhouse and Smith, 83.

${ }^{16}$ Most of the examples explored by Brickhouse and Smith appear in Chapter 2.

${ }^{17}$ Brickhouse and Smith, Socrates's Moral Psychology, 53. In writing on the Apology as the touchstone of Socratic thinking, Haraldsen, Pettersson and Tvedt, in their, Readings of Plato's Apology of Socrates: Defending the Philosophical Life (Lanham Maryland: Lexington Books 2018), summarize the scholarship well: "Early in the twentieth century it has been all but a dogma in the larger part of Anglo-American Platonic scholarship to assume that Plato's dialogues and thought can be divided into three periods reflecting a development in his thought: an early "Socratic period, a middle "mature" period, and a late period, and to regard the Apology as a touchstone of the first "Socratic period" widely regarded as representing the philosophy of the historical Socrates" (14). 
6) These "first accusers" (see 18d7-e2) and the nasty slanders they have bruited about are what led to Meletus making the formal accusation, and to Anytus and Lycon giving support to that accusation. $^{18}$

The upshot of the above summation is that those who were interrogated by Socrates acted to bring him to trial because their default feeling (pride) was damaged when Socrates exposed their ignorance to onlookers thus humiliating them. This humiliation was transmuted into anger and it was this anger that disfigured the capacity of Socrates' accusers to reason about why their pride was damaged which, again, was due to their own ignorance. Passions, anger and humiliation cannot be purely informational as the standard account would have it; at no place does Socrates suggest that they appear merely as pieces of evidence which the accusers then assess, evaluate and then act on. Indeed, such emotions are rendered as causes, full stop, which are sufficient in and of themselves to explain the accusers' actions. The accusers are dragged away by their master, humiliation, to make a false claim against Socrates and thus make the wrong choice.

More significantly, however, the reading Brickhouse and Smith provide to justify the causal features of the irrational components of soul are not merely drivers that cause agents to act externally but indeed are causally active in a second sense; they are recursively causal, an important point that the authors fail to realize fully. Let me explain.

Socrates's own account of the psychological motivation of his accusers is such that the humiliation they suffered causes this same feeling to alter becoming anger. This process of transmutation of humiliation to anger, all taking place within the psyche of Socrates's accuser, is an emotional response to Socrates's withering method of elenchus. The cause, however, for this alteration of affect is not reason, rationality, or cognition seemingly, but is due to the uncomfortable emotional dissonance the accusers are now experiencing. This churning of unsettling emotional activity produces something new, anger. Humiliation, shame and embarrassment, eventually solidifiy into the sediment of fury and both a new emotion and state of mind are produced culminating in a new plan of action- "I must take revenge upon Socrates!" Thus, affects do not simply drive one to act at the behest of the leading emotion but indeed are responsible for the creation and formation of new emotions within the psyche itself.

${ }^{18}$ Brickhouse and Smith, 56. 
Turning now to the philosophical accounts of the traditional reading, one problem in Brickhouse and Smith's view, is with the phrase dunamis tou phainomenou or the power of appearance. ${ }^{19}$ The issue here is that it is unclear how desires or fears can appear to be greater than they truly are. Restricting ourselves to The Protagoras, it seems to be the case that temporal and spatial proximity, all by themselves, are the causes for enhancing the pleasurable features of Penner's pastry/cookie examples or, conversely, magnifying the painful characteristics of cautery. But notice what is causally active under the standard view: the judgment. And yet even according to Penner, the mere proximity of the cookie acts on my perception and causes me to reverse my prior judgment to stick with my diet. The description provided by Penner himself to explain the power of appearance clearly has some causal impact on my perceptual and, later, evaluative assessment of objects I typically desire. Proximity to pleasurable or painful things alters and distorts the very information I receive prior to making a judgment.

Even if, however, one was able to resolve these interpretative problems, there is a phenomenological issue with the informational approach to desire and fear. Consider what Reshotko writes regarding drives and urges:

Unintellectualized drives and urges...in my view never play a role that is more instrumental than any other piece of information that the intellect used in order to determine what is best to do as motivated by the desire for the good. I hold that appetites are like sense impressions: they are phenomena that help us to form judgments but they do not interact with judgments that have already been formed. ${ }^{20}$

However, as Brickhouse and Smith note, a key feature of drives and urges is that they do in fact drive or urge us either towards something pleasurable or away from something painful. They do this, seemingly, all by themselves. That is not the case with sense impressions which in themselves do not. ${ }^{21}$ Thus, for these two reasons (one interpretative and the other philosophical) Brickhouse and Smith argue for a renewed interpretation of Socratic moral psychology.

\footnotetext{
${ }^{19}$ Brickhouse and Smith, 70-73

${ }^{20}$ Naomi Reshotko, Socrates Virtue: Making the Best of the Neither-Good-Nor-Bad (Cambridge University Press, 2006: 86).

${ }^{21}$ Brickhouse and Smith, 52.
} 
In contrast to the standard model's focus on rational desires and measurement, Brickhouse and Smith home in on the phrase dunamis tou phainomenou. This phrase, they argue, has not been sufficiently scrutinized in the secondary literature. It is taken for granted that what Socrates means is that some things such as pastries and cauterization may appear differently in relation to their temporal or spatial proximity to a person. That seems clear. What is not clear, Brickhouse and Smith note, is just why some things have the power of appearance at all. Nor is it clear in what way the craft of measurement "makes the appearances lose their power". ${ }^{22}$ Their argument, in effect, grounded as it is on several passages from the early dialogues, is that strong or weak passions have a causal effect on orthos logos and therefore it is due to the under-regulation of one's appetites or emotions that accounts for the target of some drive to take on an enhanced appearance. ${ }^{23}$ The stronger the appetite, the more convincing this power will be. In a reversal of the standard view then it is not that ethical knowledge somehow disperses the clouds of temptation as it were, but the reverse, one has ethical knowledge because the skies are never really that cloudy to begin with. ${ }^{24}$

This insightful and unique view of Socrates's psychology is also contrasted with the positions put forward by Plato in his middle work (most notably Book IV of The Republic) and Aristotle's view of akrasia in sections 1110b, 25 and 11113b, 25 of the Nicomachean Ethics. Whereas for the former, it is the case that "at least sometimes or in some cases, our appetites could lead us to act in ways that were contrary to what we believed-even as we acted-were best for us $\langle\ldots\rangle$ and where for the latter passions could de-activate reason, momentarily, causing one to make a mistake regarding one's practical reasoning". ${ }^{25}$ Brickhouse and Smith argue in direct contrast to these two great Greek philosophers, that reason is neither momentarily deactivated nor overrun by a more powerful desire. It is rather the case that the capacity to measure objects in terms of their true worth is compromised. Their rather nuanced account holds that desires still present themselves as

\footnotetext{
${ }^{22}$ Brickhouse and Smith, 70.

${ }^{23}$ Brickhouse and Smith, 106.

${ }^{24}$ This is a reference to Brian Lightbody's book on Plato, Dispersing the Clouds of Temptation, Eugene OR: Wipf and Stock, 2015.

${ }^{25}$ Brickhouse and Smith, 199
} 
appearances as the informational stance would have it, but they are overvalued by reason because of the weak conditioning of the body. ${ }^{26}$

This new rendering of Socratic Intellectualism by Brickhouse and Smith does much to resolve the tension, as the authors demonstrate, between rationality and emotion in the early Platonic works. However, the authors are not out of the proverbial woods just yet, for the reading they advance leads to a causal dilemma, a chicken-egg paradox. It is a concern they don't fully acknowledge. Knowledge, here understood as measurement, is still required to prevent weak-willed action but notice that the necessary condition for executing the capacity for knowledge lies in keeping one's appetites in check. Yet it is surely the case that measuring plays a causal role in balancing these very appetites. If this were not so, then measurement, here understood as ratio, would not be the most powerful attribute we possess as humans, a claim both Socrates and Protagoras come to acknowledge before and after section 352 of Protagoras. The question then is this: Which comes first? Regulated appetites or knowledge?

The way out of this paradox is to reject a model of causality that makes rigid conceptual distinctions between causes and effects. I suggest employing a conception of causality developed by John Heil to resolve this problem. Heil rejects a Dretzkean trigger approach to causality where the effect is baked into the cause, as it were, and instead develops what he calls a "powers approach". Heil's best example of his causing relationship approach is the playing card-house analogy. If one were to take two playing cards and prop them up forming a triangle house, what, he asks, is the cause of the structure? According to Heil, one would need to note several causal relationships: The cards are in a causal relation of mutual, structural support, the table acts as a foundation for the cards giving both cards stability, and gravity would be another cause forcing the cards to slope downward. Though a person was the initial productive cause for propping the cards up and thus forming the house, once this original causal relation is removed other relations must hold to explain the reasons for the continued existence of the house built from cards. ${ }^{27}$

\footnotetext{
26 This conclusion is repeated in several places within Socrates's Moral Psychology. Good summations of the argument can be found on p. 129 and p. 200.

${ }^{27}$ John Heil, The Universe as we Find It (New York Oxford University Press 2012: 119).
} 
I believe this powers approach to causality is applicable to the new Socratic model proffered by Brickhouse and Smith. It explains further the causal relationship between appetites and pathos on the one side and measurement on the other. In addition, it solves the chicken-egg paradox above and instead substitutes a framework of virtuous and vicious feedback loops. Let me explain.

Brickhouse and Smith have established that appetites and measurement exist in a causing relationship according to Socrates: the more unbridled the appetites the more difficult it is to measure, which leads to an enervation of the capacity to measure itself. Taken in its full measure, it leads to a state of miserable wretchedness a circumstance of

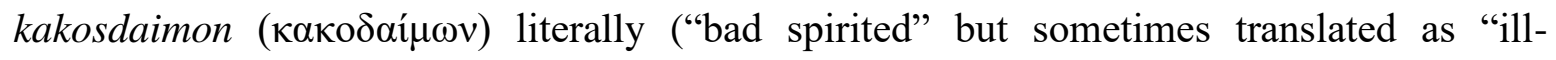
starred") briefly and prophetically discussed by Socrates in 77C-78A of the Meno. In that section, Meno argues against the Socratic dictum that those who do evil do so out of ignorance. He agrees with Socrates that there are those who pursue harmful things thinking, mistakenly, such things are good when they are not. As such these individuals act out of ignorance. But Meno also thinks there is a second group of people who know they are causing harm to themselves through their actions. In taking up this argument, Socrates does not directly refute Meno's point, namely that someone who pursues bad things knows he will be harmed by such things. What Socrates argues is not that people do not want harmful things knowing they are harmful, but that it is impossible for people to want to gain possession of such things with the knowledge that the gaining of [enough] harmful things will lead to a state of misery.

Soc.: Well, and do those who, as you say, desire evils, and think that evils are hurtful to the possessor of them, know that they will be hurt by them?

Meno: They must know it.

Soc.: And must they not suppose that those who are hurt are miserable in proportion to the hurt which is inflicted upon them?

Meno: How can it be otherwise?

Soc.: But are not the miserable ill-fated?

Meno: Yes, indeed.

Soc.: And does any one desire to be miserable and ill-fated?

Meno: I should say not, Socrates. (Meno 77 e-78a trans. Jowett)

No one desires to be ill-fated (also translated as unhappy or miserable), all can agree on that point. But what the second group is ignorant of is not that the object of lust before them is harmful, because they are fully aware that. What they are unaware of is the 
proportion of hurt that will be inflicted upon them through the pursuit of this harmful thing. They lack the capacity to measure properly, the object in relation to themselves. Putting the matter more forcefully, what Meno's second group are ignorant of is the extent to which the action of pursuing harmful things will come to corrode one's very ability to reason, making one in a sense part of the damned, the ill-fated.

But notice that if we adopt Brickhouse and Smith's model along with a model of causality advanced by Heil the opposite of what happens to the ill-starred would be true: the more robust one's capacity to measure the easier it is to rein in one's appetites, which in turn leads to a stronger capacity to measure. One may be caught in either vicious or virtuous circles depending on the pre-existing causal relationship that obtains between appetites, pathos and measurement.

\section{Applying The New Socratic Model to Plotinus}

I now wish to use this new conception of Socratic psychology as a lens through which to examine Plotinus's account of akrasia. One of the initial problems facing scholars who seek to reconstruct Plotinus' understanding of weakness of will is the sheer paucity of the term's appearance in Enneads. According to Robert Van Den Berg, there is in fact only one passage in Plotinus's entire philosophical corpus where the word akrasia may be found (see "Treatise against the Gnostics" (Enn. II 9 [33] 15). ${ }^{28}$ Scholars have turned, then, to passages that focus on the relationship between soul, body, evil and most significantly for my purposes, the manner in which temptation appears to a self who identifies with its bodily composite and not its Soul.

Where then to begin? One often cited passage is Ennead I.8 (14) 44-50 and so I will begin here too. This passage is particularly problematic given the standard reading of Plotinus's metaphysical system of emanationism where the basic principle here is that the inferior, in this case matter, cannot causally influence that which is superior, which, in this case, is Soul. ${ }^{29}$ Solving this paradox is key to understanding Plotinus' view of akrasia. The

\footnotetext{
${ }^{28}$ Van Den Berg, "Plotinus’s Socratic Intellectualism”, 217

${ }^{29}$ See Enneads, II 416 3-8. John Rist's classic article presents highlights the main features of matter. See his "Plotinus on Matter and Evil", Phronesis Vol. 6, No. 2 (1961), pp. 154-166.
} 
Socratic "causing" reading which I argue for does just that. Turning now to the passage in question, Plotinus writes:

This is the fall of the soul, to come in this way to matter and to become weak, because all its powers are not activated; matter prevents their presence by occupying the place that matter holds and in a way by making its condition constricted and by making evil what it got hold of by a sort of theft, until soul is able to escape. Matter is thus the cause of weakness in the soul and the cause of evil." (Enn I 814 44-50 Armstrong)

In his masterful work Plotinus: An Introduction, O’ Meara views the above passage as the most troublesome in Plotinus's corpus with respect to the ancient Egyptian philosopher's plea that agents alone are morally responsible for their actions and should conduct themselves accordingly by focusing on the virtues contained within the soul and not the appetites of the body. He presents the problem clearly. After taking up the standard explanation for moral failing, namely, that of ignorrance, he declares that, "Moral evil arises through the ignorance brought about by infatuation with body. Thus body (and therefore matter) must exist already for moral evil to occur. Moral evil is a consequence, and not a cause, of metaphysical evil". ${ }^{30}$ However this rendering leads to the naturally inferred question based on Plotinus's emmanationism: 'How could metaphysical evil understood by Plotinus as a privation produce moral evil?' 'How can that which is defined as lack have causal properties? ${ }^{31}$ A straightforward answer to these paradoxical questions O'Meara declares, "would mean that matter prevails over soul, the inferior over the superior, which seems impossible."32 "Is there some flaw in soul that allows it to be influenced by matter?" O’Meara ponders but then notes "Plotinus insists that this is not the case." O'Meara's gloss on this passage before moving on to other elements of Plotinus's philosophy is telling: "Yet it is hard to see how matter could be entirely responsible for soul's vice. This would mean robbing soul of moral responsibility for its actions". ${ }^{33}$

Gerson in quoting the above section too, in his "Plotinus on Weakness of Will: A Neo-Platonic Synthesis", is well-aware of the problems this passage engenders. He tries to

${ }^{30}$ Dominic J O’Meara, Plotinus: an Introduction to the Enneads, (Oxford University Press 1993: $85)$.

${ }^{31}$ Enneads II .6, II .5 (25) III. 6 (26) VI 3, 44.

32 O'Meara, 85.

${ }^{33}$ O’Meara, 85. 
offer an alternative interpretation by combining it with Ennead 2.3.9: "Each of us is double: one being the composite and one being the self". Gerson in effect does an end-run around the paradox by arguing that Plotinus offers a "synthesis" view. With these two passages in mind, Gerson presents the following reconstruction of the relationship between the composite (namely soul and body) and one's true self (Soul) this way. Wrongdoing is caused by ignorance specifically ignorance of the soul's true identity, namely what is wrong or bad simpliciter and what is wrong or bad for oneself, that is the composite. ${ }^{34}$ This confusion, for Gerson, rests with the composite in failing to understand what it truly is, a soul entombed within a constrictive material body. Yet the body remains privative because the soul, always in communion with the Intellect, utilizes the forms found therein to realize unqualified goods. These goods, however, appear distorted because of the material formlessness of body the Self, as composite takes and thus what appears to be a good such as engaging in some illicit vice to cure some pain, is not in reality. ${ }^{35}$

Now thus far this position is in keeping with Brickhouse and Smith's interpretation above. The body presents images for the higher Soul's analysis but the soul as composite, takes such images as ones that should be pursued even when they are not truly in its best interest. Gerson, however, moves on from this robust Socratic reading to posit his own unique synthesis interpretation of weakness of will in Plotinus. It is here where is reading goes awry. According to Gerson the struggle between true Self and composite is reminiscent of the distinction employed by Harry Frankfurt between first order and second order desires. Thus, just as Frankfurt claims that we are sometimes furrowed in that we have desires, say for pastry, these appetites battle with our higher, second-order wants. ${ }^{36}$ These second-order desires seek intellectual sustenance, namely contemplation of the Forms and not the physical pleasures of the body. ${ }^{37}$

Given this Frankfurtian model, the nexus of Soul and composite, then, according to Gerson is truly conflicted; akrasia is very much a real thing. The self as composite thinks

\footnotetext{
${ }^{34}$ Gerson, "Plotinus on Weakness of Will: The Neoplatonic Synthesis", 51.

${ }^{35}$ Gerson, 55

${ }^{36}$ See Harry Frankfurt, "Freedom of the Will and the Concept of a Person", Journal of Philosophy, 68.1 (1971) 5-20.

${ }^{37}$ Gerson, 54.
} 
that a first-order desire, a temptation of the body say, is good when really if it was able to understand and answer the question Gerson concludes his paper with, Who am I? would enact its second-order desire, namely not to be encumbered by the desires of the body in the first place. ${ }^{38}$ The second-order desire would be to contemplate the Forms found in the Intellect untrammeled by the vicissitudes of the body. The body, then, for Gerson, does not simply present images to the mind for further evaluation and subsequent pursuit or avoidance. Rather these images are themselves desires/fears which either motivate the composite (soul and body) to move toward or avoid. Akrasia, then is real for Plotinus according to Gerson.

There are two related problems with Gerson's analysis. First, Gerson frames the problem of a divided self as the inability of the self to answer the fundamental question of Plotinus: Who am I? Yet, in framing the problem as a failure to articulate an answer to a discursive question, it is implied the solution, if not completely intellectual, is primarily so. We've seen that this is not true for Socrates - the conditioning of one's body may occlude the correct answer to this question or indeed prevent the question from even arising in the individual so tempted. More to the point, I would argue it is not true for Plotinus. Consider what Plotinus counsels one should do in Enneads 4.4 18 15-19 in order to avoid identifying wholly with the composite: "For this reason, we are concerned with its (body's) pleasures and pains the more concerned the weaker we are, and to the extent that we do not separate ourselves, but posit it as the most honorable part of us and the human being and sink ourselves into it". This idea of "sinking oneself" into one's bodily appears to be precisely what Socrates advocates to avoid doing according to Brickhouse and Smith's reading. As they show there are many places where Socrates argues we must regulate our bodily appetites in order to measure objects correctly.

To be clear, Gerson does acknowledge that the managing of one's bodily temptations plays a role in Self-determination because, "for Self-Determination for one so embodied has to be found in virtue, by which Plotinus means "moral virtue". ${ }^{39}$ But consider this: if first-order desires are real desires and not just informational akin to sense impressions (as the standard view would have it) then it is difficult to understand how Soul,

\footnotetext{
${ }^{38}$ Gerson, 57.

${ }^{39}$ Gerson, 56.
} 
as the emanation of Intellect, can deactivate them. Furthermore, Plotinus's general solution to the problem that the body poses to one's salvation is that of a viva contemplativia-one cures one's vices through understanding one's true nature, as a manifestation of Intellect precisely as Gerson suggests. But then Plotinus's solution would be seem to be at odds with the true ontological problem, that of a furrowed self, if Gerson's interpretation is correct. Surely a much better therapeutic approach to control bodily desires would be the position taken up by the middle Plato who suggests that the dark passions of the soul must be yoked to a higher purpose or perhaps Aristotle who suggests that our appetites at the appropriate times and the appropriate manner should be loosened or vented so as to prevent them from over-running the better parts of the soul. Thus, if we accept Gerson's solution to akrasia, namely that Self fails to understand what it truly is, then "there cannot be, as Van Den Berg argues, a conflict between a first-order desire and a second-order desire based on a critical evaluation of the first-order desire. The first-order desire is the only one there is". ${ }^{40}$

Van Den Berg himself attempts to defend a more robustly construed Socratean reading of Plotinus. His interpretation marks a significant improvement over Gerson's model. As already noted, he takes umbrage with Gerson's attempt to introduce a Platonic kind of akrasia into Plontius's thought. In the middle dialogues Plato conceives of the self as furrowed. The soul has different and competing desires: appetitive, competitive and contemplative. ${ }^{41}$ Thus, the soul may be directed to material wealth or rich foods not because he or she is mistaken about their true value as with the Socratean model, but because reason itself may be dragged away by appetite to pursue an object whose satisfaction it knows not to be in its best interests. The desire to have such things comes from a distinct part of the soul itself. ${ }^{42}$

Van Den Berg, in contrast, argues that there are not second-order desires but that the Soul is prevented from doing its job because it is a composite-the body blocks the Soul from performing a correct evaluation of an object. The key passage for Van Den Berg is

\footnotetext{
${ }^{40}$ Van Den Berg, "Plotinus' Socratic Intellectualism”, 224.

${ }^{41}$ Plato, Republic Book IV. For an insightful interpretation of Plato's arguments concerning the division of soul see R.F. Stalley "Plato's Argument for the Division of the Reasoning and Appetitive Elements within the Soul", Phronesis 20.2 (1975) 110-128.

42 The principal argument to show that every person has a better and worse part and that antagonistic desires come from each can be found in Republic, Book IV, 431a-b.
} 
the troublesome passage noted above-Enneads 18 40-51. His modified translation of Armstrong's rendering of the passage quoted is in keeping with the main features previously explained:

[T.6] This is the fall of the soul, to come in this way to matter and to become weak ( $\dot{\alpha} \sigma \theta \varepsilon v \varepsilon i v)$

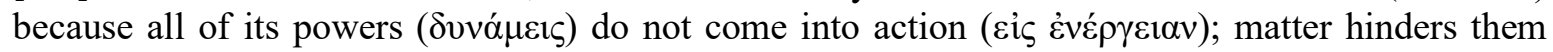
from coming by occupying the place which soul holds and producing a kind of cramped condition, and making evil what it has got hold of by a sort of theft - until soul manages to escape back to its higher state. (Enn. I 8 [51] 14, 44-49; trans. Armstrong, modified by Van Den Berg)

Van Den Berg attempts to reconcile the seeming paradox of a clearly lower order influencing a higher one by trading, not on a hierarchy of desires as Gerson does, but on the idea of appearance and image. For Van Den Berg, we have no choice but to evaluate the worthiness of objects presented before our mind because we are composites. The body is responsible for showing Soul, illuminated by Intellect, images for proper judgement. But if we fail to cast judgment on such objects and are led to make the wrong choice, then we act involuntarily. We are not acting on a lesser desire as Gerson thinks but on ignorance. ${ }^{43}$ The key passage for Van Den Berg in fleshing out this interpretation is the following,

The so-called thinking of falsities is an appearance (phantasia) that did not await the judgment of discursive reason, but we acted since we were persuaded by our worse parts, just as in the case of sense perception it happens to the perception of the joint entity to see falsely before discursive reasoning has passed judgment. Intellect was either in touch or it was not, and therefore did no wrong. (Enn. I 1 [53] 9, 6-15).

The main take-away of the passage is that objects cannot be evaluated by Soul independently of the body because it is the body which presents objects to the Soul, as appearances, for evaluation in the first place. We commit the wrong choice when we misevaluate such images by not using the full powers of the Soul. Such failure is due to our own ignorance. We are to blame for our bad actions, not the body.

In summarizing his discussion of these key Plotinian passages, Van Den Berg writes, "For Plotinus, the "weakness of soul" does not consist in the fact that the worse opinion or desire overcomes the better one, but in the inactivity of the soul". ${ }^{44}$ This summation combined with the causal powers approach to the body, as I will explain below,

\footnotetext{
${ }^{43}$ Van Den Berg, 228.

${ }^{44}$ Van Den Berg, 227.
} 
is all Van Den Berg needs in order to solve the paradox of Enneads I 8, 51 40-49. However, Van Den Berg then goes on to ascribe causal properties to the body thus inviting the very perplexity O’Meara explains above. He writes, "His (Plotinus's) point is that matter is responsible for the evil of the soul, because it "obscures," the soul thus preventing it from seeing the illumination that comes from above, i.e., from Intellect, and from actualizing its full potential". 45

And yet it is unclear how precisely the body essentially discombobulates Soul given that the body as matter simply marks formlessness while the soul is impassive and thus cannot be influenced directly by the body. Van Den Berg hits upon the right solution in suggesting that the Soul has no control over the images it receives from the body but does not then speculate why nor how on some occasions the body actively obscures the very capacity of the Soul to receive divine light from Intellect.

Gary Gabor in his commentary on Van Den Berg's article puts the above objection well. "The higher soul, Plotinus informs us, cannot be said to have any failing in this regard, since it is either "in touch with the proceedings (of Intellect) or not" (I $1[53] 9,13)$. But something must be said to fail, and it seems to me that the proper place to locate it is in the lower soul's failure to submit to instruction by the higher soul". ${ }^{46}$ Gabor has no way of extricating Plotinus from the paradox and concludes that, "The most consistent reading is that Plotinus endorses Socratic intellectualism and the possibility of hard akrasia. And Plotinus, I believe, is entirely aware of this paradox". ${ }^{47}$ Even the great mind Plotinus, seemingly, cannot extricate himself from the very paradox he creates.

But there is a way out of the paradox. By employing the new Socratic model of Brickhouse and Smith, however, one may claim that considering engaging in vice as a reasonable course of action for one in a given circumstance, is not just a failure to identify with one's true nature but also reflects the composite's distortion of what is truly valuable as caused by the condition of one's body. The composite fails to be receptive to the instruction of the higher soul not because it fails to listen to its true self, as Gerson explicitly suggests and Van Den Berg only intimates but because it over-estimates the

\footnotetext{
${ }^{45}$ Van Den Berg, 227.

${ }^{46}$ Gabor, “Commentary on Van Den Berg (Plotinus's Socratic Intellectualism)”, 234

${ }^{47}$ Gabor, 236.
} 
appearance of some object or action. Such over-estimation occurs because the body is in a weak condition. Let me explain.

Notice that the irresolvable paradox O'Meara and Gabor note regarding the capacity of the body to alter the evaluation of Soul appears only if one assumes a strict division of cause and effect relationships. That is to say, the problem manifests itself if one assumes a traditional Socratic intellectualist stance which holds that the body may only present information for the mind to consider and that it is the mind that is completely causally and, therefore, absolutely morally responsible if it gives undue value to these deceptions. The paradox diasppears once one accepts a causing explanation regarding the role between soul and body. In this way one can affirm precisely what Plotinus avers in the above passage namely that matter prevents this presence (the powers of the soul to see through deception) by making it contract (that is undermining soul's ability) to see phainomenou dunamis for what it truly is and insteading over-estimating the value of a given vice.

Yet since an over-estimation is not real qua appearance, Plotinus's position regarding matter as privation remains intact while those who do act out of vice do so involuntarily. Why? "Because we will not designate the actions of evil persons, who do many things according to their imaginings, as up to them, or voluntary, where as we will designate those who are self-determining who, owing to the activities of intellect are free from the affections of the body" (Enneads, 6.8.3). As long as we are not free from the affections of the body, we are not entirely free from the body's capacity to present the background which allows the very images the mind will assess for further evaluation. After all, if there was just the One the very appearances of objects required for Soul's assessment would not be present and both virtue and vice would be irrelevant. Indeed if nothing emmanated from the One then neither Soul nor Intellect would exist and the very discussion of weakness of will would be a moot point. So-called appetites of the body, for Plotinus then, given this new Socratic psychological model, act as distorted reflectors of the Good - they are incapable of illuminating objects by themselves and likewise incapable of providing impulsion for the composite without the irradiating light from Soul.

Matter is analogous to darkness, a point made by Plotinus on many occasions (see especially Enneads I 8, 14). Metaphorically speaking, the body manifests a dark 'background' that serves to sever the metaphysical connection of objects to each other 
presenting them, to the higher Soul, "in touch with the proceedings of Intellect" as disconnected singular objects of "good" that should be purused. Yet it is this very higher soul that evaluates this image as truthful and it is this higher soul that pursues the object in question. Body, as privation, is not causally responsible in innitating our desire to pursue some illicit temptation, but does have a causing role to play vis a vis our evaluation.

The body as matter possess privative but not causal features which neither block nor obscure the Soul's ability to view an object of lust correctly, as Van Den Berg claims. It is the case rather, that these privative features darken the illuminating light from Intellect and thus the Self cannot see the object in its totality, that is the object's more fundamental connection to the Whole, the One. But if darkness is purely privative then so too is matter. The more we pursue appetites the darker the background of said images become-we focus and pursue the object qua object and not the source of emanation itself, the One. In this sense Van Den Berg is correct in noting that the body 'obscures' the Soul's activity, but he is wrong when he attributes causal properties to the body itself. That is his mistake. The body has a "causing" role to play in that the more unregulated the appetites of one's body the darker the background some object of Soul's assessment becomes and thus the more likely the composite will zealously pursue the object not fully understanding why. Van Den Berg remains captured by the informational view of Socrates and as a result he does not come full circle to the conclusion I offer here.

In conclusion, some of the recent work in the secondary literature that presents Plotinus as a defender of Socratic intellectualism is not incorrect per se just underdetermined-one can present a non-standard reading of Socrates's intellectualism and apply it to Enneads. The position taken up by Brickhouse and Smith is one example of a non-standard but incredibly insightful interpretation that can provide new insight on Plotinus's Socratic intellectualism. Their view has two distinct advantages over the traditional and in their words "informational" account of Socratic moral intellectualism. 1) It better aligns with commonsense intuitions regarding the phenomenology of desires, namely, that desires, all by themselves, have propulsive properties that cause us to want to act irrespective of some evaluation; 2) it is more coherent with other passages of the early Plato than the standard view. With that said, their assessment remains incomplete in that they have not provided a satisfactory account that explains the causal structure of this new 
Socratic intellectualist view. I argued that Heil's causal powers approach fleshes out this obvious lacuna in their work.

Finally, it was shown that the underdetermination of Socratic Intellectualism has grave import with respect to interpreting Plotinus's view of akrasia. One of the chief problems in interpreting Plotinus as a Socratean has to do with the importance he gives to the body as the source of evil. Yet, since the body is also described as a privation, there appears to be a paradox in that Plotinus is claiming that the body qua privation is causally inert and thus cannot be a cause for action and so therefore it must be Self's evaluation of some temptation that causes it to commit evil actions. The solution to the paradox ranges from the supplemental view of Gerson to the more robust Socratic views of Van Den Berg and, to a degree, Gabor. All three interpretations, however, share the same foundation which is of the traditional "informational" interpretation of Socratic intellectualism. As such their solution to the problem of weak-willed action is roughly the same: evil is committed when the Self identifies with its composite and not its true nature. What they fail to explain is how the Self identifies with the composite at all if the composite is causally inert.

My explanation fills in this gap by showing that privation and causal inertness are not identical: a negative property such as the fragility of a vase explains, in part, why the vase when dropped on a hard surface shattered and yet the vase's fragility is not a cause in a positive sense for the breaking of the vase. We are perfectly justified in holding a person responsible for breaking a vase if he drops said vase on the floor. Analogously, the body is simply the dark 'background' that makes objects deemed worthy of pursuit to standout from others. The blacker the background some object has, the more value it appears to have to the Self. In other words, our failure to regulate our appetites causes Self to pursue these same appetites with more gusto leading to a vicious circle in that we pursue illicit objects with reckless abandon leading to a life of vice, debauchery and wretchedness and yet it is a life that we are responsible for even if it is involuntarily chosen.

Brian Lightbody

Brock University 


\section{Bibliography}

Brickhouse. Thomas and Smith, Nicholas. Socratic Moral Psychology, Cambridge U.K: Cambridge University Press 2010.

Davidson, Donald. "How is Weakness of Will Possible", in Essays on Actions and Events, Philosophical Essays, Vol. 1. Oxford University Press 2001.

Frankfurt, Harry. "Freedom of the Will and the Concept of a Person". Journal of Philosophy, 68.1 (1971), 5-20.

Gabor, Gary. "Commentary on Van Den Berg” (Plotinus's Socratic Intellectualism), Proceedings of the Boston Area Colloquium in Ancient Philosophy, Vol. XXVIII 2012, eds. Gary M. Gurtler, SJ, and William Wians, Brill: Leiden/Boston 2013, pp. 232-240.

Gerson, Lloyd. "Plotinus on Weakness of Will: The Neoplatonic Synthesis" in Weakness of Will From Plato to the Present, Ed. Tobias Hoffman Washington; D.C.: Catholic University of America Press 2008, 42-57.

Haraldsen, Pettersson and Tvedt. Readings of Plato's Apology of Socrates: Defending the Philosophical Life (Lanham Maryland: Lexington Books) 2018.

Heil, John. The Universe as we Find It. New York: Oxford University Press 2012.

Lightbody, Brian. Dispersing the Clouds of Temptation: Turning Away from Weakness of will and Turning Towards the Sun. Eugene, OR: Wipf and Stock 2015.

Mele, Alfred. Backsliding: Understanding Weakness of Will, New York: Oxford University Press 2014.

O’Meara, Dominic J. Plotinus An Introduction to the Enneads. New York: Oxford University Press 1993.

Penner, Terry. "Socrates and the Early Dialogues". The Cambridge Companion to Plato, Richard Kraut Ed. Cambridge U.K: Cambridge University Press, 1992, 121-169.

Penner, Terry. "Knowledge vs. True Belief in the Socratic Psychology of Action". Apeiron, 3 1996, 199-230.

Plato. Protagoras Plato the Complete Works, ed. John M. Cooper, trans. Stanley Lombardo and Karen Bell. Indianapolis: Hackett Publishing 1997.

Plato, Meno and Other Dialogues (Charmides, Laches, Lysis), trans. Robert Waterfield. Oxford University Press 2005.

Plotinus. Enneads, Volume I-VIII: Translated by A. H. Armstrong. Loeb Classical Library 440. Cambridge, MA: Harvard University Press 1969.

Reshotko, Naomi. Socrates Virtue: Making the Best of the Neither-Good-Nor-Bad. Cambridge University Press 2006.

Rist, John. "Plotinus on Matter and Evil”, Phronesis Vol. 6, No. 2 (1961), pp. 154-166.

Stalley, R.F. "Plato's Argument for the Division of the Reasoning and Appetitive Elements within the Soul", Phronesis 20.2 (1975) 110-128.

Van Den Berg, Robert. "Plotinus's Socratic Intellectualism", Proceedings of the Boston Area Colloquium in Ancient Philosophy, Vol. XXVIII eds. Gary M. Gurtler, SJ, and William Wians, Brill: Leiden/Boston 2013, pp.217-231. 